\title{
KARAKTERISTIK MATERI PEMBELAJRAN TAHSINUL QUR'AN BERBASIS NEUROSAINS
}

\author{
Muh. Fatkhul Mubin ${ }^{*}$ \\ 1* Muhammadiyah Boarding School (MBS) Pleret, Bantul, Indonesia
}

Keyword: Material characteristic, Learning Tahsinul Qur'an, Neurosains

Kata Kunci:

Karakteristik

Materi,

Pembelajaran

Tahsinul Qur'an, Neurosains

\begin{abstract}
The learning of tahisinul Qur'ān to enable Muslims to read the Qur'ān with tarteel has still become a challenge in Indonesia. Its factors include the complexity and complicatedness of makhārijul huruf and Arabic sounds' characteristics. This qualitative research aims at explaining forms of material delivery and material components in books for tahsinul Qur'ān learning. Its data were from nine books used as public as well as restricted learning resources. The content analysis was applied using neuroscience, especially related to the characteristics of learning materials, which might be boring or enjoyable and difficult or easy based on the brain functions. Findings show that 1) There are eight forms of material delivery: theory, examples, excercises, pictures, encoding-decoding, diagram, summary, and evaluation. Only one book has all eight forms. Examples and exercises appear in all books, encoding-decoding and evaluation in four books while pictures and summary in three books; 2) The learning materials consist of four components: learning guidelines, guidance for reciting the Qur'ān, hijaiyah sounds, and Ibtida' and Waqaf. Only three books contain all components. Variation of forms in material delivery makes the materials enjoyable and easy for learners. Sufficient material components are also important to support effective taḥsinul Qur'ān learning.
\end{abstract}

\section{ABSTRAK}

Pembelajaran taḥsinul Qur'ān sebagai syarat membaca al-Qur'ān dengan tartil masih menjadi tantangan di Indonesia. Beberapa faktor penyebabnya terkait dengan kompleksitas dan kerumitan makhārijul huruf dan sifatsifatnya. Tujuan penelitian ini adalah menjelaskan bentuk-bentuk penyajian dan komponen-komponen materi yang ditemukan pada buku-buku pembelajaran tahsinul Qur'ān. Penelitian kualitatif ini menggunakan data yang berasal dari sembilan buku pembelajaran tahsinul Qur'ān untuk masyarakat umum atau kalangan terbatas. Analisis konten dilakukan dengan berbasis neurosains, terutama terkait dengan karakteristik materi pembelajaran yang membosankan, menyulitkan, menyenangkan, dan memudahkan yang selaras dengan fungsi dan cara kerja otak. Hasil penelitian menunjukkan bahwa 1) Terdapat delapan bentuk penyajian pembelajaran, yaitu teori, contoh, latihan, gambar, encoding-decoding, bagan, ringkasan, dan evaluasi. Hanya satu buku yang memiliki kedelapan bentuk penyajian tersebut. Contoh dan latihan ditemukan pada semua buku. Encoding-decoding, evaluasi, gambar, dan ringkasan ditemukan pada sebagian buku; 2) Materi tahsinul Qur'ān meliputi empat komponen, yaitu petunjuk pembelajaran, aturan, kaidah, atau adab membaca Qur'àn, huruf hijaiyah, dan Ibtida' \& Waqaf. Hanya tiga buku yang memiliki semua komponen materi. Berdasarkan neurosains variasi bentuk akan membuat materi menjadi menyenangkan dan memudahkan pembelajar sehingga perlu diperhatikan. Komponen materi yang lengkap perlu juga diperhatikan oleh penulis buku untuk mendukung efektifitas pembelajaran tahsinul Qur'ān. 


\section{PENDAHULUAN}

Kebanyakan umat Islam di Indonesia belum tartil dalam membaca al-Qur'ān (Sa'diyah, 2013). Hanafi, Murtadho, \& Ikhsan (2019) menemukan bahwa di sebuah universitas negeri di Malang lebih dari 86\% mahasiswa yang mengambil mata kuliah Pendidikan Agama Islam (PAI) tahun akademik 2017/2018 memiliki kemampuan rendah dalam membaca al-Qur'ān. Murniyetti (2012) juga menyatakan hal yang sama terjadi di sebuah universitas negeri di Padang. Hanafi, dkk, (2019) juga menyimpulkan bahwa hampir semua perguruan tinggi negeri memiliki kondisi serupa. Padahal, kemampuan membaca al-Qur'ān yang baik berperngaruh positif terhadap prestasi belajar (Arsyad dan Salahuddin, 2018;

Esensi al-Qur'ān adalah firman Allah berbahasa Arab yang dituturkan dengan tartil (Ilyas, 2019) dan oleh sebab itu setiap muslim dituntut dapat membaca al-Qur'ān dengan tartil. Rasulullah SAW membacanya dengan tartil pula, oleh karena itu membaca al-Qur'ān hukumnya sunnah (Supriyanto, Juanda, Solechan, \& Hidayani, 2007). Bahkan Humam (2005) menyatakan bahwa membaca secara tartil hukumnya wajib 'ain. Kesalahan dalam menuturkan ayat-ayat alQur'ān merupakan pelanggaran terhadap larangan dalam membaca al-Qur'ān (Annuri, 2019), di samping dapat merubah bangunan kata dan maknanya. Penguasaan materi tahsinul Qur'ān secara teoretis dan praktik merupakan proses bagi seorang muslim untuk membaca al-Qur'an dengan tartil (Sudiarjo, Mariana, \& Nurhidayat, 2005; Qowim, 2019).

Materi pembelajaran yang baik menunjang tercapainya kompetensi inti dan kompotensi dasar (Prastowo, 2017). Kompetensi inti merupakan tingkat kemampuan yang harus dikuasai pembelajar sebagai standar kelulusan dari suatu program (Iriani \& Ramadhan, 2019). Kompetensi dasar menggambarkan pengetahuan, ketrampilan, dan sikap minimal yang wajib dikuasai pembelajar sebagai bukti bahwa pembelajar telah mencapai kompetensi dasar yang ditetapkan (h. 57). Ada tiga prinsip penyusunan materi pembelajaran, yaitu 1) relevansi: materi memiliki keterkaitan dengan pencapaian kompetensi dasar dan kompetensi inti; 2) konsistensi: materi memiliki keajekan dalam memuat pembahasan sesuai dengan kompentensi dasar yang harus dikuasai; dan 3) kecukupan: materi pembelajaran mencukupi untuk membantu siswa mencapai kompetensi dasar (h. 57).

Penyusunan materi tahsinul Qur'ān juga penting memperhatikan tiga prinsip tersebut di atas (relevansi, konsistensi, dan kecukupan). Menurut Nursalim (2012) ada tiga prinsip dalam membaca al-Qur'ān dengan tartil, yaitu: 1) fasih melafalkan huruf hijaiyah sesuai tempat-tempat keluar (makhārijul) huruf dan sifat-sifatnya dalam segala kondisi; 2) konsisten dengan notasi (harakat); dan 3) menguasai pembacaan ayat-ayat asing/gharibah. al-Qudhat yang dikutip oleh Majid (2020) salah satu sarat membaca al-Qur'ān harus memiliki sanad yang benar, masyhur, dan tidak asing.

Pembelajaran akan efektif jika pengajar mendudukkan pembelajar sebagai individu yang aktif dan terlibat dalam pembelajaran sehingga suasana pembelajaran menjadi konduksif (Huda, 
2019), aktif, menyenangkan, dan mengaktifkan area-area otak (Suyadi, 2017), dan menantang serta melibatkan emosi positif pembelajar (Widiana dan Bayu, 2017). Kemampuan pengajar menentukan strategi pembelajaran yang tepat dalam mendekati, merancang, dan mengatur pembelajaran sesuai kebutuhan dan potensi pembelajar menjadi ciri pengajar ideal (Huda, 2019). Pengajar sangat penting memperhatikan cara kerja otak, karena semua bahasa, persepsi, dan penalaran fungsi motorik tertumpu pada otak (Damasio, 2009).

Artikel berbasis penelitian ini merupakan respon atas studi pembelajaran tahsinul Qur'ān yang sudah ada, dengan fokus pada materi tahsinul Qur'ān yang bagi banyak pembelajar terasa sulit dipahami dan diingat. Penelitian ini bertujuan untuk mengidentifikasi pembelajaran yang sulit bagi pembelajar dan menunjukkan pembelajaran yang mudah serta menyenangkan sebagai solusi masalah pembelajaran taḥsinul Qur'ān. Materi pembelajaran tahsinul Qur'ān yang menyenangkan, menantang, memotivasi, dan memudahkan pembelajar dalam memahaminya merupakan ciri materi pembelajaran berbasis neurosains (Suyadi, 2017)

Penelitian ini didasarkan pada argumen bahwa kesulitan mempelajari materi tahsinul Qur'ān bagi bangsa non Arab dapat diatasi dengan pembelajaran materi taḥsinul Qur'ān yang menyenangkan dan menantang melalui, karakteristik materi pembelajaran tahsinul Qur'ān berbasis neurosains. Dengan demikian, umat Islam tertarik dan termotivasi mempelajarai tahsinul Qur'ān sehingga dapat membaca al-Qur'ān dengan tartil sesuai perintah Allah dalam surat al-Muzammil ayat empat. Oleh karena itu, penelitian ini penting untuk dilaksanakan.

\section{METODE PENELITIAN}

Penelitian ini merupakan studi kepustakaan dengan pendekatan kualitatif. Penelitian kualitatif menggunakan data tekstual yang dianalisis berdasarkan interpretasi (Miles, Huberman, \& Sadana, 2014). Sumber data utama penelitian ini diambil dari sembilan buku belajar membaca dan tahsinul Qur'ān yang didukung dengan berbagai literatur baik berasal dari al-Qur'ān, buku maupun jurnal, berita online, yang terkait dengan pembelajaran tahsinul Qur'ān dan berbasis neurosains. Pengumpulan data dilakukan dengan penelusuran dan pembacaan referensi terkait baik secara manual maupun digital.

Data utama berasal dari sembilan buku yang membahas belajar membaca al-Qur'ān dan taḥsinul Qur'ān. Tujuh buku digunakan oleh publik, dan dua buku secara khusus digunakan mahasiswa, masing-masing digunakan mahasiswa dua universitas di Yogyakarta. Judul kesembilan buku itu adalah: (1) Buku Iqro' Cara Cepat belajar membaca al-Qur'ān (Humam, 2000); (2) Cara Cepat Belajar Tajwid Praktis (Humam, 2005); (3) Tahsinul Qur'ān Universitas Ahmad Dahlan (Suwarno, at al., 2019); (4) Modul Pembelajaran al-Qur'ān: Diadopsi dari Buku 10 Jam Belajar Membaca al-Qur'ān (LPPI UMY, 2019); (5) Tajwid \& Tahsin: Kaidah Tata Cara Membaca al- 
Qur'ān dan Tempat Keluarnya Huruf Disertai Sifat-sifatnya (al-Quro, tt); (6) Tuntunan Ilmu Tajwid Praktis (Saeruddin \& Robith, 2011) (7) Panduan Tahsin Tilawah al-Qur'ān \& Ilmu Tajwid (Annuri, 2019); (8) Al-Wadhih fi Ahkami at-Tajwid, Panduan Lengkap Belajar Ilmu Tajwid Otodidak (al-Qudrat, Ter. Majid, 2020); (9) Quantum Tahsinul Qur'ān (Sholihuddin, 2008).

Data dari sembilan buku tersebut di atas dikumpulkan berdasarkan bentuk penyajian materi dan komponen-komponen materi tahsinul Qur'ā. Data yang terkumpul didisplai dan dianalisis secara induktif dengan mengedepankan intelektualitas. Analisis data bentuk penyajian materi tahssinul Qur'ān bertujuan mengetahui bentuk penyajian yang membosankan dan yang menyenangkan, serta menemukan bentuk penyajian lain yang selaras dengan kerja alamiah otak. Analisis komponen-komponen materi tahsinul Qur'ān untuk mengetahui komponen apa saja yang menunjang pada kemampuan membaca al-Qur'ān dengan tartil.

\section{HASIL DAN PEMBAHSAN}

Terkait dengan tujuan penelitian, disajikan hasil analisis data tentang penyajian materi tahsinul Qur'an yang bersumber dari sembilan buku tahsinul Qur'ān, yang mengandung dua pokok temuan, yaitu varian bentuk penyajian materi pada Tabel 1, dan komponen materi pembelajaran yang disajikan pada Tabel 2.

Tabel 1. Bentuk Penyajian Materi Tahsinul Qur'an

\begin{tabular}{|c|c|c|c|c|c|c|c|c|c|}
\hline \multirow{2}{*}{ Bentuk Penyajian } & \multicolumn{9}{|c|}{ Buku Ke } \\
\hline & (1) & (2) & (3) & (4) & (5) & (6) & (7) & (8) & (9) \\
\hline 1. Teori & - & $\sqrt{ }$ & $\sqrt{ }$ & - & $\sqrt{ }$ & $\sqrt{ }$ & $\sqrt{ }$ & $\sqrt{ }$ & $\sqrt{ }$ \\
\hline 2. Contoh & $\sqrt{ }$ & $\sqrt{ }$ & $\sqrt{ }$ & $\sqrt{ }$ & $\sqrt{ }$ & $\sqrt{ }$ & $\sqrt{ }$ & $\sqrt{ }$ & $\sqrt{ }$ \\
\hline 3. Latihan & $\sqrt{ }$ & $\sqrt{ }$ & $\sqrt{ }$ & $\sqrt{ }$ & $\sqrt{ }$ & $\sqrt{ }$ & $\sqrt{ }$ & $\sqrt{ }$ & $\sqrt{ }$ \\
\hline 4. Gambar & - & - & - & - & $\sqrt{ }$ & - & $\sqrt{ }$ & $\sqrt{ }$ & - \\
\hline 5. Encoding-Decoding & - & - & - & - & - & $\sqrt{ }$ & $\sqrt{ }$ & $\sqrt{ }$ & $\sqrt{ }$ \\
\hline 6. Bagan & - & $\sqrt{ }$ & - & - & - & - & $\sqrt{ }$ & $\sqrt{ }$ & - \\
\hline 7. Ringkasan & - & - & - & - & - & $\sqrt{ }$ & $\sqrt{ }$ & $\sqrt{ }$ & - \\
\hline 8. Evaluasi & $\sqrt{ }$ & - & $\sqrt{ }$ & - & - & $\sqrt{ }$ & - & $\sqrt{ }$ & - \\
\hline
\end{tabular}

Keterangan: (1) - (9) : Judul buku (berdasarkan urutan pada Bagian metode penelitian)

$$
\begin{aligned}
& \text { V. : Menyajikan } \\
& \text { - }: \text { Tidak Menyajikan }
\end{aligned}
$$


Tabel 2. Komponen Materi Pembelajaran

\section{Komponen}

Buku Ke

\begin{tabular}{l|l|l|l|l|l|l|l|l|l} 
& (1) & (2) & (3) & (4) & (5) & (6) & (7) & (8) & (9) \\
\hline 1. Petunjuk Pembelajaran & $\sqrt{ }$ & - & $\sqrt{ }$ & $\sqrt{ }$ & - & - & $\sqrt{ }$ & $\sqrt{ }$ & $\sqrt{ }$ \\
\hline 2. Peraturan Membaca Al-Qur'an & - & - & - & - & - & - & $\sqrt{ }$ & $\sqrt{ }$ & $\sqrt{ }$ \\
\hline $\begin{array}{l}\text { 3. Huruf Hijaiyah: Tempat artikulasi, sifat- } \\
\text { sifat, dan hukum Tajwid }\end{array}$ & & & & & & & & & \\
\hline Makharijul Huruf & - & $\sqrt{ }$ & - & - & $\sqrt{ }$ & $\sqrt{ }$ & $\sqrt{ }$ & $\sqrt{ }$ & $\sqrt{ }$ \\
\hline Sifat-sifat Huruf & - & $\sqrt{ }$ & - & - & $\sqrt{ }$ & $\sqrt{ }$ & $\sqrt{ }$ & $\sqrt{ }$ & $\sqrt{ }$ \\
\hline Nun Sukun & $\sqrt{ }$ & $\sqrt{ }$ & $\sqrt{ }$ & $\sqrt{ }$ & $\sqrt{ }$ & $\sqrt{ }$ & $\sqrt{ }$ & $\sqrt{ }$ & $\sqrt{ }$ \\
\hline Mim Sukun & $\sqrt{ }$ & $\sqrt{ }$ & $\sqrt{ }$ & $\sqrt{ }$ & $\sqrt{ }$ & $\sqrt{ }$ & $\sqrt{ }$ & $\sqrt{ }$ & $\sqrt{ }$ \\
\hline Ghunnah & $\sqrt{ }$ & $\sqrt{ }$ & $\sqrt{ }$ & $\sqrt{ }$ & $\sqrt{ }$ & $\sqrt{ }$ & $\sqrt{ }$ & $\sqrt{ }$ & $\sqrt{ }$ \\
\hline Mad & $\sqrt{ }$ & $\sqrt{ }$ & $\sqrt{ }$ & $\sqrt{ }$ & $\sqrt{ }$ & $\sqrt{ }$ & $\sqrt{ }$ & $\sqrt{ }$ & $\sqrt{ }$ \\
\hline Lam Ta'rif & $\sqrt{ }$ & $\sqrt{ }$ & $\sqrt{ }$ & $\sqrt{ }$ & $\sqrt{ }$ & $\sqrt{ }$ & $\sqrt{ }$ & $\sqrt{ }$ & $\sqrt{ }$ \\
\hline Qalqalah & $\sqrt{ }$ & $\sqrt{ }$ & $\sqrt{ }$ & $\sqrt{ }$ & $\sqrt{ }$ & $\sqrt{ }$ & $\sqrt{ }$ & $\sqrt{ }$ & $\sqrt{ }$ \\
\hline Hamzah Washal dan Qath'i & $\sqrt{ }$ & $\sqrt{ }$ & - & - & - & $\sqrt{ }$ & $\sqrt{ }$ & $\sqrt{ }$ & $\sqrt{ }$ \\
\hline Tafkhim \& Tarqiq & - & $\sqrt{ }$ & - & - & $\sqrt{ }$ & $\sqrt{ }$ & $\sqrt{ }$ & $\sqrt{ }$ & $\sqrt{ }$ \\
\hline Keragamaan Bacaan Al-Qur'an & - & $\sqrt{ }$ & - & $\sqrt{ }$ & - & $\sqrt{ }$ & $\sqrt{ }$ & $\sqrt{ }$ & $\sqrt{ }$ \\
\hline 4. Ibtida' dan Waqf & - & $\sqrt{ }$ & $\sqrt{ }$ & - & - & $\sqrt{ }$ & $\sqrt{ }$ & $\sqrt{ }$ & $\sqrt{ }$ \\
\hline
\end{tabular}

Bentuk penyajian materi tahsinul Qur'ān (Tabel 1) dalam buku-buku yang diteliti ada delapan varian, yakni teori, contoh, praktik, gambar, encoding-decoding, bagan, ringkasan, dan evaluasi. Pembahasan kedelapan varian tersebut untuk mengetahui relevansinya dengan pembelajaran tahsinul Qur'ān berbasis neurosains.

Teori. Teori meliputi penjelasan suatu faktor tertentu (Suriasumantri, 2017), termasuk regularitas, dan memberikan pemahaman yang lebih tepat atas fenomena yang dikaji dari suatu disiplin ilmu. Keberadaan teori dalam penyajian materi tahsinul Qur'ān dapat memberikan penjelasan dan gambaran ontologis dari materi yang disajikan.

Keberadaan teori dapat menyamakan persepsi bagi pengajar dan pembelajar tentang esensi materi yang sedang dikaji. Teori tahsinul Qur'ān yang tersusun secara sistematis dan aplikatif dapat mengaktifkan sistem limbik sehingga menelurkan emosi postif dan memotivasi pada pembelajar untuk melakukan penalaran pada neokorteks. Cara kerjan sistem limbik di antaranya mengendalikan emosi dan menyimpan memori (Hendri, 2010), Entitas fungsional sistem limbik saling terkait dan berinteraksi antara komponen-koponennya dengan area-area otak lainnya (Sousa, 2012), dan menerima informasi kemudian mengolah (meneruskan atau menghentikan) informasi ke otak neokorteks (Suyadi, 2017). Sedangkan, otak neokorteks (otak berpikir) berfungsi untuk 
berpikir, mengingat, mempersepsi, membuat analogi, mengambil keputusan, berseni, dan menikmati seni (Said \& Rahayu, 2017).

Terlihat pada Tabel 1 ada enam dari sembilan buku memuat teori. Buku tahsinul Qur'ān yang tidak memuat teori mengimplikasikan bahwa keberhasilan pembelajaran tertumpu pada kompetensi pengajar semata. Pembelajar tidak mengetahui ukuran kebenaran dari materi yang diajarkannya. Hal ini dapat menimbulkan keraguan bagi pembelajar dewasa bahkan pengajarnya sendiri.

Keraguan dalam pembelajaran menimbulkan kekawatiran pada otak reptil. Proses penalaran dan motivasi belajar menjadi rendah akibat defence oleh otak reptil yang disebabkan oleh rasa kawatir tersebut (Said dan Rahayu, 2017). Cara kerja otak reptil yang utama adalah merespon stimulan dengan melawan atau lari bila ada ancaman, rasa takut, kawatir atau ketidaknyamanan lainnya (Said dan Rahayu, 2017), di samping berkaitan dengan hal mendasar dalam keberlangsungan hidup dan reaksi spontan (gerak reflek) terhadap rangsangan yang berasal dari pancaindra. (Suyadi, 2017). Oleh karena itu adanya kawatir pembelajar dalam belajar mengakibatkan neokorteks tidak dapat berpikir dengan baik sehingga sulit dalam memahami materi dan menyimpanya ke dalam memori jangka panjang.

Contoh. Contoh merupakan bentuk aktualisasi dari teori. Esensi al-Qur'ān adalah tuturan, maka teori dari materi tahsinul Qur'ān lebih mudah dipahami dengan contoh. Lebih mudah lagi jika materi pembelajaran memberikan banyak contoh dan dituturkan langsung oleh pengajar di depan pembelajar, seperti Rasulullah mengajarkan al-Qur'ān kepada para sahabat dengan menuturkan. Penyampaian bacaan al-Qur'ān dari Jibril kepada Nabi Muhammad dicontohkan dengan tuturan yang tartil, dan Rasulullah SAW pun melakukan hal yang sama kepada para sahabatnya, berlanjut kepada para tabi'in dan para tabi'in-tabi'in, dan seterusnya (Annuri, 2019).

Semakin banyak contoh materi tahsinul Qur'ān yang dituturkan pengajar semakin mudah pula pembelajar memahaminya. Pembelajar terbantu dengan melihat gerak mimik pengajar dan pembelajar dapat mengikutinya. Tiga gaya belajar pembelajar yaitu audio, visual, dan kinetik (Suyadi, 2017) dapat terpenuhi apabila pengajar menuturkan banyak contoh materi tahsinul Qur'ān.

Sistem pembelajaran tahssinul Qur'ān yang paling tepat dan dicontohkan Rasulullah adalah talaqqi (al-Qudhat, melalui Majid, 2020). Sistem talaqqi relevan dengan pemberian contoh melalui penuturan materi tahsinul Qur'ān oleh pengajar.

Kemampuan pengajar menuturkan huruf-huruf al-Qur'ān dengan benar (bersanad sampai Rasulullah) menjadi kunci utama keberhasilan pembelajaran tahsinul Qur'ān. Semakin banyak pembelajar memperoleh contoh tuturan materi tahsinul Qur'ān yang benar dari pengajar, semakin mudah pembelajar menuturkannya sesuai karakteristik bahasa Arab dan sebaliknya. Melalui proses belajar seperti ini, pembelajar dapat mengaktifkan memori prosedural atau ingatan karena 
kebiasaan dengan berpikir konvergen fokus pada materi yang berkaitan dengan ketrampilan motorik (Suyadi, 2017: 45).

Hasil analisis terhadap kesembilan sumber data menunjukkan bahwa semua buku menyajikan contoh. Namun hanya tiga buku yang banyak memberikan banyak contoh, yaitu buku ke (1), (3), dan (4). Keenam buku lainnya memberi contoh yang relative sedikit sehingga materi yang tersimpan dalam memori prosedural kurang berkualitas. Buku yang menyajikan banyak contoh selaras dengan prinsip kerja otak, yakni semakin sel saraf difungsikan maka semakin berkualitas (Suyadi, 2017). Contoh dari materi tahsinul Qur'ān yang sering diulang dan dipraktikkan akan memperkuat koneksi antar sel sehingga penguasaan materi menjadi mendalam dan mempengaruhi karakter penuturannya.

Latihan/praktik. Praktik meupakan aplikasi teori yang telah dipahami. Keberhasilan mempelajari materi tahsinul Qur'ān dipengaruhi oleh banyak praktik yang intensif. Penuturan merupakan ketrampilan mengucapkan, oleh karena itu praktik seharusnya memiliki porsi lebih besar dari pada teori. Praktik menuturkan huruf hijaiyah sesuai makhraj dan sifaf-sifatnya yang dilakukan berulang-ulang dan kontiyu dapat membentuk karakter penuturan huruf hijaiyah yang benar. Terlebih Banyak praktik dapat membentuk sirkuit sel saraf baru dan jika dilakukan dengan berkelanjutan dapat membentuk karakter (Awhinarto dan Suyadi, 2020), apalagi dibarengi dengan emosi potif materi dapat disimpan dalam memeori panjang. Karena, Peristiwa yang melibatkan emosi kuat akan tersimpan dalam memori yang panjang (Ardianto, 2017).

Bahasa al-Qur'ān memiliki karakter yang berbeda dengan bahasa Indonesia khususnya pada aspek fonetiknya Hidayat (2012). Kemampuan seorang muslim membaca al-Qur'ān dengan tartil dapat diwujudkan dengan memperbanyak praktik menuturkan bahasa al-Qur'än dengan benar. Seorang muslim yang membiasakan menuturkan ayat-ayat al-Qur'ān dengan benar, maka karakter bahasa al-Qur'ān akan mengkristal pada dirinya.

Otak reptil terasah dengan banyak praktik, dan jika dilakukan berulang-ulang akan menjadi gerak reflek. Seorang yang terbiasa menuturkan ayat dengan benar maka ketika membaca ayat-ayat al-Qur'ān otomatis benar walaupun tanpa melibatkan otak neokorteks dan sistem limbik. Kemampuan pengucapan fonetik bahasa al-Qur'ān yang berbeda (tidak semuanya sama) dengan fonetik bahasa Indonesia menjadi salah satu bukti keberhasilan mempejari tahsinul Qur'ān.

Pratik penuturan materi tahsinul Qur'ān dengan tingkat intensitas yang tinggi dan didasari penguatan sistematis, memudahkan terbentuknya karakter penuturun baru. Hal ini sesuai dengan teori pembelajaran model Barr dan Tagg, terutama point empat dan lima yaitu pembelajaran melatih pembelajar mengaplikasikan ilmu dan berpusat pada pembelajar (Huda, 2019).

Penuturan ayat-ayat al-Qur'ān yang benar disebabkan praktik penuturun yang benar dan berulang-ulang. Begitu juga sebaliknya penuturan ayat-ayat al-Qur'ān yang salah disebabkan 
praktik penuturun yang salah dan berulang-ulang. Prinsip kerja otak adalah pembiasaan yang sistematis dapat mengubah struktur otak pada tingkat sinaps karena terbentuknya sirkuit baru pada otak dan menjadi karakter (Awhinarto \& Suyadi, 2020). Oleh karena itu pembiasaan penuturan ayat-ayat al-Qur'ān dengan benar syarat mutlak untuk dapat membacanya dengan tartil.

Praktik yang didasari oleh susunan teori tahsinul Qur'an yang benar, sistematis dan aplikatif dapat membentuk karakter penuturan ayat-ayat al-Qur'ān dengan benar. Berdasarkan hasil analisis sembilan buku tahsinul Qur'ān, hanya dua buku yang banyak menyajikan materi latihan yaitu buku kesatu dan ketujuh (Tabel 1).

Gambar. Penyajian materi dengan gambar pada pokok bahasan makhārijul huruf mempermudah pembelajar menguasai materi. Pembelajar mengetahui dengan pasti tempat huruf berada dan asal huruf keluar. Berdasarkan gaya belajar visual, persepsi pembelajar mudah terbangun dengan melihat gambar (Suyadi, 2017), dibanding memahami melalui teori semata.

Sistem limbik dan otak neokorteks mudah menyimpan informasi dalam memori setelah menerima informasi tersebut dari pengelihatan. Namun, dari sembilan buku sumber data hanya tiga buku (buku 3, 5 dan 8) yang menyajikan materi letak atau tempat huruf keluar melalui gambar (Tabel 1). Padahal, visualisasi merupakan cara belajar efektif, dan terlebih lagi gambar yang berwarna memudahkan materi tersimpan dalam memori jangka panjang (Suyadi, 2017).

Encoding-decoding merupakan pengubahan informasi sensoris oleh pemberi informasi kepada penerima dalam bentuk yang mudah diterima dan diingat oleh keduanya. Encodingdecoding dalam pembelajaran berfungsi sebagai penghubung antara konsep (materi) yang masih asing (sulit) dengan konsep yang sudah diketahui.

Encoding-decoding dapat dilakukan dengan metode chunking, yaitu merangkai atau mengelompokkan beberapa huruf menjadi kata (small chunks) atau beberapa kata menjadi frase (larger chunks) atau beberapa frase dirangkai menjadi kalimat (even larger chunks). Penyajian materi dengan encoding-decoding mendorong pembelajar berpikir kritis imajinatif dan kreatif dalam memahami materi melalui analogi atau asosiasi.

Pada Tabel 1 terlihat ada empat buku yang menyajikan materi melalui Encoding-decoding yaitu buku keenam, tujuh, delapan, dan sembilan. Keempat buku tersebut menyajikan materi dengan encoding-decoding pada pokok bahasan sifat-sifat huruf yang berlawanan.

Misalnya, dalam menyajikan huruf-huruf bersifat idzlâq (ر- م- ن- ل-ف- ب), keempat buku tersebut merangkai huruf-huruf tersebut menjadi beberapa frase (larger chunks) فئ جن ن لـب (firra min lubbin), dan buku ketujuh menambah alternatif lain yaitu

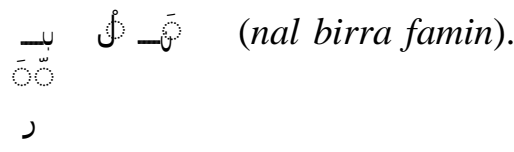

Pembelajar bisa menghafal firra min lubbin atau nal birra famin dengan lebih mudah dibanding menghafal huruf-huruf $\left(f a^{\prime}, b a^{\prime}\right.$, lam, nun, mim, $\left.r a^{\prime}\right)$. Pengkodingan seperti di atas mempermudah mengingatnya walaupun masih dalam memori jangka pendek (Hasanuddin, 2017). 
Penyajian materi dengan encoding-decoding dari keempat buku tersebut akan menjadi lebih mudah jika disesuaikan dengan frase yang sudah akrab dengan pendengaran muslim Indonesia.

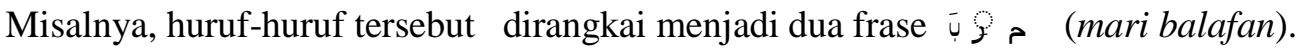

$$
\text { ن }
$$

Frase 'mari balafan' secara morfologis mirip dengan 'mari balapan' sehingga s tidak asing lagi bagi pendengaran orang Indonesia. Dengan kemiripan tersebut, pembelajar di Indonesia akan lebih mudah mengingatnya dibandingkan dengan frase 'firra min lubbin' atau 'nal birra famin'. Berbeda halnya dengan orang yang setiap hari berbahasa Arab. Bagi mereka frase 'firra min lubbin' atau 'nal birra famin' lebih mudah dipahami dan diingat dari pada frase 'mari balafan'.

Frase 'mari balafan' bukan hanya akrab di telinga muslim Indonesia, namun maknanya pun dapat dipahami dengan mudah. Dengan demikian pembelajar dapat melakukan semantic coding (mengingat arti dari kata), bahkan memungkinkan imagery coding (membayangkan reaksi seseorang yang mempraktikan frase itu) (Hasanuddin, 2017: 236).

Keempat buku tersebut dapat dikembangkan juga dalam penyajian materinya. Setelah memahami huruf-huruf yang bersifat Idzlâq, pembelajar dapat menalar huruf-huruf yang bersifat Ishmāt dengan memegang sebuah kunci, yaitu selain huruf yang bersifat Idzlāq, pasti bersifat Ishmāt.

Pembelajaran melalui encoding-decoding merupakan proses belajar yang menantang, pembelajar termotivasi untuk menguasai materi, sistem limbik dan otak neokorteks aktif melakukan penalaran dalam rangka memahami dan menyimpan memori ke dalam storage otak. Dengan demikian pembelajaran tahsinul Qur'an melalui encoding-decoding merupakan salah satu ciri pembelajaran berbasis neurosains. Contoh menghafal huruf-huruf yang bersifat idzlâq dengan menggunakan encoding-decoding sebagai berikute د- م- ن- ل-ف (fa', ba', lam, nun, mim, ra') dapat dirangkai menjadi kata dan kalimat yang mudah diingat (small chunks-even larger chunks) \& $\bar{\rho}$ f (mari balafan).

i Encoding-decoding menimbulkan kesan mudah diterima, sehingga sistem limbik dapat memproduksi emosi positif dan neokorteks melakukan penalaran dan menyimpannya ke dalam memori jangka panjang. Kesan mudah mengingat materi terjadi karena penalaran analogi pada otak neokorteks. Penalaran analogi merupakan proses penalaran dengan membandingkan satu konsep yang masih asing dengan konsep yang tidak asing untuk diambil kesimpulan (Azmi, 2017), dengan mencari persamaan atau keserupaan tanpa memperhatikan perbedaan di antara dua hal yang dibandingkan, dan menggunakan kesamaannya (Kariadinata, 2012: 4).

Bagan, merupakan bentuk materi yang efektif untuk menyajikan pokok bahasan atau ringkasan materi dalam bentuk gambar atau tulisan. Komponen pada bagan yang dihubungkan dengan garis menunjukkan adanya saling keterkaitan secara struktural di antara dua atau beberapa materi. 
Bagan yang disajikan di awal pembahasan merupakan gambaran pola materi pembelajaran. Bagan yang disajikan di akhir pembahasan merupakan ringkasan dari materi. Keduanya mempermudah pembelajar memahami materi yang disajikan.

Penyajian materi tahsinul Qur'an dengan bagan sangat membantu jalannya pembelajaran yang efektif. Dari Tabel 1 terlihat baru tiga buku yang memanfaatkan bagan sebagai bentuk penyajian materi. Dengan bagan pembelajar lebih mudah merekam inti keseluruhan materi pembelajaran. Fungsi bagan seperti gambar sehingga otak neokorteks lebih mudah menalar dan menyimpan ke storage karena menerima informasi dari pengamatan.

Evaluasi, merupakan alat untuk mengukur tingkat keberhasilan pembela-jar dalam menacapai tujuan pembelajaran yang ada. Hasil evaluasi dapat menjadi feedback dalam usaha meningkatkan efektifitas pembelajaran dan langkah-langkah selanjutnya. Tabel 1 menunjukkan hanya empat buku yang memuat evaluasi.

Keberadaan evaluasi juga dapat menjadi tantangan yang harus diselesaikan oleh pembelajar. Pembelajar dapat termotivasi dengan adanya evaluasi sehingga berusaha dengan penuh kesungguhan dalam belajar.

Ada beberapa penyajian materi yang sesuai dengan kerja alamiah otak, namun belum dimanfaatkan kesembilan buku tersebut di atas untuk menyajikan materi tahsinul Qur'ān seperti parodi lagu, narasi, video, dialog, dan rumus praktis.

Parodi lagu, bisa menjadi bentuk materi yang efektif untuk penguasaan materi tahsinul Qur'an khususnya pokok bahasan makhārijul huruf dan sifat-sifatnya. Parodi lagu dapat menstabilkan emosi pembelajar dan berimplikasi pada pembelajaran yang menyenangkan, memudahkan pembelajar menelurkan emosi positif pada sistem limbik (Said \& Rahayu, 2017; Suyadi, 2017). Dengan lagu, materi bisa dihafal dengan lebih mudah, seperti misalnya lagu-lagu yang digunakan untuk menghafal asmaul husna.

Parodi lagu dapat berfungsi sebagai ice breaking di tengah pembelajaran untuk menstabilkan konsentrasi pembelajar (Said \& Rahayu, 2017). Contoh prodi lagu yang dapat dimanfaatkan, misalnya, lagu 'Gundul-gundul Pacol' dan 'Tik-tik Bunyi Hujan', dengan penyajian materinya sebagai berikut:

1.Parodi Lagu 'Gundul-gundul Pacul'
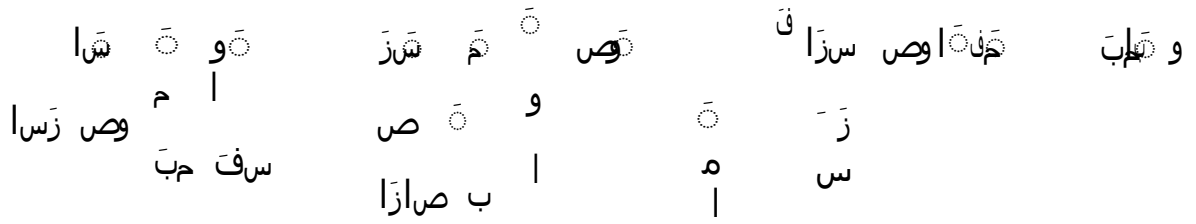


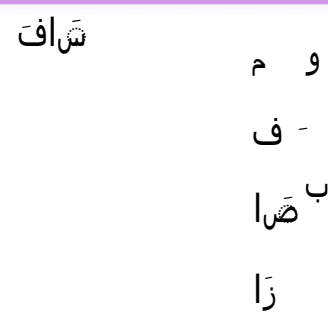

1.Parodi lagu 'Tik-tik Bunyi Hujan'

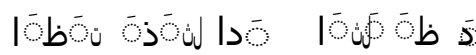

$$
\begin{aligned}
& \text { ظ طَ }
\end{aligned}
$$

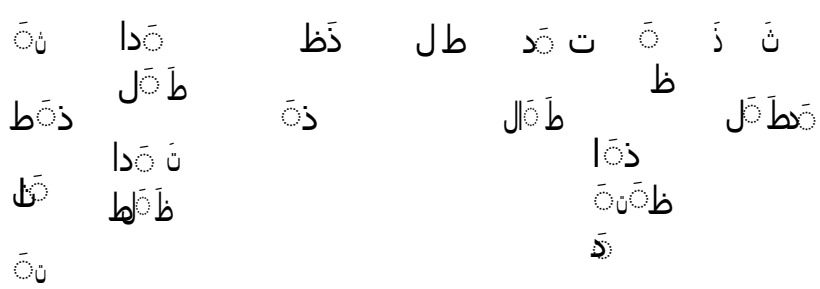

$$
\begin{aligned}
& \text { ظ }
\end{aligned}
$$

Kedua parodi lagu tersebut membiasakan pengucapan huruf-huruf hijaiyah berdasarkan rumpun makhraj huruf. Materi tersusun berdasarkan urutan dari makhraj terluar (di antara dua bibir) dan masuk secara berurutan ke rumpun dalam terdekat dari bibir bawah dan berakhir di tenggorokan paling bawah.

Parodi lagu juga dapat digunakan untuk pengayaan materi dalam penuturan huruf-huruf hijaiyah yang benar, seperti parodi lagu "Di Sini Senang di Sana Senang. Sebagai contoh adalah pengayaan huruf wawu dengan lirik seperti berikut:

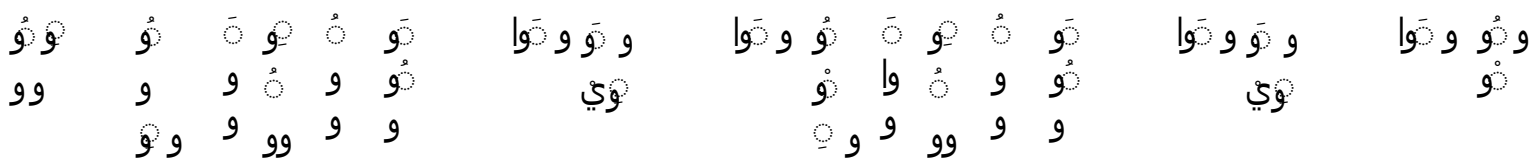

$$
\begin{aligned}
& 9
\end{aligned}
$$

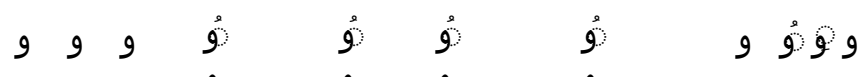

$$
\begin{aligned}
& \begin{array}{llll}
9 & 9 & 9 & 9 \\
9 & 9 & 9 & 9
\end{array}
\end{aligned}
$$


Proses pembelajaran yang dikemas dalam parodi lagu menjadi ciri salah satu pembelajaran yang hidup, menyenangkan, dan mengesankan. Pembelajaran yang menyenangkan dan mengesankan dapat menstabilkan emosi (Muhimmah \& Suyadi, 2020).

Parodi lagu menarik minat pembelajar untuk terlibat secara aktif dalam pembelajaran, sehingga pembelajar diharapkan bisa fokus pada nyanyian, terutama jika dilakukan bersama-sama. Keaktifan pembelajar dalam proses pembelajaran memudahkan materi terkuasai sehingga tujuan pembelajaran mudah pula tercapai (Trinova, 2012)

Parodi lagu sangat cocok untuk penyajian materi yang bersifat hafalan (Said \& Rahayu, 2017), seperti materi makhârijul huruf dan sifat-sifatnya. Pengulangan dan pembiasaan pengucapan makhârijul huruf yang benar, seperti disajikan dalam parodi lagu 'Di Sini Senang di Sana Senang', sangat membantu pembelajar untuk mengulang-ulang materi tanpa harus melihat buku.

Pengulangan berkali-kali dapat merangsang otak dan sangat memungkin terbentuknya sirkuit baru sampai menjadi karakter (Awhinarto \& Suyadi, 2020), termasuk karakter pengucapan huruf Al-Qur'ān yang benar. Penyajian materi makhârijul huruf dan

sifat-sifatnya yang dikemas dalam parodi lagu akan menghidupkan sistem limbik dan otak neokorteks akan bekerja dengan lebih baik sehingga dapat memudahkan pembelajar memproses materi ke dalam memori yang baik dan mudah untuk diingat kembali.

Rumus praktis, merupakan istilah yang digunakan untuk memahami materi berdasar rumus sederhana. Rumus praktis digunakan untuk menampung berbagai cara mudah memahami konsep dengan sederhana, mudah diingat dan dapat digunakan sebagai patokan untuk mengetahui konsep lain yang berkaitan.

Sebagai contoh adalah saat menyajikan materi dengan pokok bahasan mim sukun. Untuk memahami mim sukun cukup dengan memahami huruf $b a$ ' dan mim. $B a$ ' diasosiasikan dengan kata 'bapak' dan mim dengan kata 'mama'. Rumus praktisnya, jika ada mim sukun bertemu dengan huruf $b a$ ' ('bapak') atau huruf mim ('mama') maka mim sukun wajib dibaca 'manja' (berdengung tiga ketukan). Contohnya 'Wamāhummm bimu'minīn', 'walakummm māaltum'. Kemudian rumus praktis yang berlaku, bila ada mim sukun bertemu huruf selain 'bapak' atau 'mama' dibaca jelas tidak boleh manja, contohnya 'lam yalid walam yûlad'.

Rumus praktis merupakan cara berpikir sederhana, imajinatif dan kreatif, menantang, serta memotivasi. Materi yang disajikan dengan rumus praktis menjadi mudah dipahami dan diingat, dan pembelajarannya pun bisa menjadi cair dan menyenangkan. Sistem limbik dan otak neokorteks akan bekerja dengan baik karena indra menangkap suasana pembelajaran yang menyenangkan dan mudah diterima tanpa ada ancaman atau yang dikawatirkan (Said \& Rahayu, 2017).

Narasi, merupakan pendeskripsian suatu objek melalui kata-kata yang tersusun dalam suatu 
kalimat sehingga entitas dari objek mudah diterima oleh sistim limbik dan diteruskan kepada neokorteks untuk dinalar dan disimpan dalam storage. Penyajian materi dalam bentuk narasi bisa mendukung praktik pembelajaran cara mengucapkan huruf-huruf hijaiyah yang benar (sesuai makhraj dan sifat-sifat masing-masing huruf). Dengan narasi entitas huruf hijaiyah mudah dipahami oleh otak.

Misalnya narasi untuk mendeskripsikan cara mengucapkan huruf mim. Narasi bisa dibuat untuk memberikan gambaran tempat keluar (makhraj) huruf mim, yaitu berada di antara dua bibir tertutup, dan dilanjutkan dengan penjelasan sifat-sifatnya: Jahr, Tawassuth, Istifâl, Infitâh, Idzlâq, Ghunnah. Narasi untuk huruf mim bisa dibuat sebagai berikut.

Cara melafalkan huruf mim: Keluarkan suara tipis dari dua bibir terbuka dan berakhir tertutup. Suara yang keluar antara tertahan dan terlepas. Kemudian tahan nafas (udara tidak boleh berembus). Lidah dari pangkal sampai ujung berada di dasar mulut, rongga mulut terbuka, serta suara harus dilewatkan ke hidung khususnya saat bertasydid, idghâm, iqlâb, atau ikhfấ.

Kesalahan yang sering terjadi saat mengucapkan huruf mim adalah melipat bibir ke dalam dan/atau tidak mendengung sempurna saat bertasydid.

Dengan narasi tersebut pembelajar mendapatkan pemahaman entitas huruf mim. Gambaran cara penuturannya yang benar menghindari kesalahan yang sering terjadi saat menuturkannya. Penalaran terjadi saat memahami entitas huruf mim dan mengingat di saat mempraktikan pengucapannya. Dengan pemahaman yang utuh tentang entitas huruf mim, pembelajar bisa menghapus keraguan atau kekawatiran dan tidak melakukan kesahalan sehingga sistem limbik dapat menghasilkan emosi positif.

Video, merupakan media pembelajaran yang sangat efektif bagi pembelajar dalam proses mengingat materi. Pembelajar saat menyaksikan video dapat melibatkan dua indra (penglihatan dan pendengaran) sekaligus, sehingga memudahkannya menangkap informasi. Informasi yang tertangkap kedua indra tersebut diteruskan ke sistem limbik dan otak neokorteks, diproses melalui penalaran dan disimpan dalam storage.

Objek atau materi pembelajaran yang tertangkap indra penglihatan lebih terkesan dan mudah diingat (Titin, 2016). Di samping itu, di saat pembelajar terlibat dalam proses pengamatan, sistem limbik menumbuhkan emosi positif memungkin-kan materi tersimpan dalam waktu panjang.

Berikut adalah contoh link penyajian materi makhārijul huruf dan sifat-sifatnya melalui media audio visual.

https://www.youtube.com/watch?v=RITSysb1QPE

https://www.youtube.com/watch?v=BSothd6saBE

https://www.youtube.com/watch?v=h3MT7uyLRF8\&t=302s

Materi yang disajikan di dalam link YouTube tersebut di atas adalah makhārijul huruf dan sifat-sifatnya, disertai proses keluarnya huruf hijaiyah yang benar. Materi audio-visual seperti ini tidak ditemukan pada kesembilan buku yang menjadi sumber data dalam penelitian ini. Dengan adanya materi berbentuk video sebagai pelengkap buku akan memudahkan pembelajar dalam 
mempelajari materi secara mandiri maupun bersama-sama serta mengulang-ulangi tanpa terbatas pada waktu dan ruang. Hal ini selaras dengan teori pembelajaran model Barr dan Tagg yang dikutip Huda (2019:11)

Proses penyimpanan materi pembelajaran ke storage otak yang baik dapat dilakukan melalui pengulangan materi secara berkelanjutan. Pengulangan materi secara kontinyu dapat dilakukan sendiri dengan memutar video kembali. Di zaman digital ini, hampir setiap orang memegang gawai sehingga materi yang disajikan dalam bentuk video yang dikoneksikan dengan internet (misalnya diunggah di YouTube) menjadi lebih mudah diakses sendiri.

Materi tahsinul Qur'ān khususnya pada pokok bahasan makhārijul huruf dan sifat-sifatnya memerlukan pengulangan yang banyak, yang dapat dilakukan dengan memutar video pembelajaran. Meskipun pembelajar belajar sendiri, ia mendapatkan panduan cara mengucapkan huruf yang benar melalui media video tersebut. Dengan demikian pembelajar bisa meminimalkan kesalahan dalam menuturkannya.

Banyaknya varian penyajian materi dapat menjaga kestabilan konsentrasi pembelajar, memudahkan pengajar dalam mengkreasi pembelajaran yang efektif, menyenangkan, menantang, memotivasi, dan mewadahi keragaman kecerdasan (multiple Intelligences) pembelajar. Hal ini sesuai dengan pembelajaran tahsinul Qur'ān berbasis neurosains. Mempertahankan penuh terhadap kinerja otak secara alami atau normal akan menghasilkan suatu fungsi yang optimal dari otak (Awhinarto dan Suyadi, 2020).

Tabel 2 menggambarkan komponen materi dari masing-masing buku dalam menyajikan materi tahsinul Qur'ān. Kelengkapan materi dari materi pembelajaran tahsinul Qur'ān merupakan keseluruhan syarat membaca al-Qur'ān dengan tartil. Satu komponen materi dengan materi lainnya saling terkaitan untuk memenuhi unsur-unsur tartil. Dari sembilan sumber data penelitian baru tiga buku yang menyajikan materi tah̆sinul Qur'ān secara utuh.

Data penelitian menunjukkan bahwa enam di antara sembilan buku yang diteliti tidak mencantumkan aturan, kaidah atau adab membaca al-Qur'ān secara tartil. Padahal membaca dengan tartil merupakan fardhu 'ain (Q.S. al-Muzammil: 4) dan syarat utama menuju tartil adalah mengetahui hukum tajwid. Muslim yang membaca al-Qur'ān dengan tajwid akan mendapat derajat yang tinggi (HR. Al-Bukhari, Muslim dan Abu Dawud; dari Aisyah) dan diberi syafaat di hari kiamat (HR. Muslim). Dicantumkannya aturan, kaidah atau adab membaca al-Qur'ān dalam bukubuku pembelajaran tahsinul Qur'an akan menumbuhkan kesadaran tentang arti penting membaca secara tartil sekaligus memotivasi mereka untuk mempelajari materi dengan serius.

Komponen materi yang juga penting untuk menunjang efektifitas pembelajaran adalah petunjuk pembelajaran. Petunjuk pembelajaran merupakan acuan bagi pengajar dalam menyampaikan tahapan-tahapan pengajaran dan tahapan-tahapan pembelajar dalam belajar, dan juga memuat target dan tujuan pembelajaran. Petunjuk pembelajaran dapat dijumpai di buku ke (1), (3), (4), (5), dan (6). Buku yang memuat petunjuk pembelajaran mendeskripsikan proses pembelajaran dan pencapaian tujuan yang terukur serta rasional. 
Contoh petunjuk pembelajaran belajar membaca Al-Qur'an yang termuat dalam buku ke (1). Buku ini terdiri dari enam jilid, dan setiap jilid ada petunjuk pembelajaran. Petunjuk pembelajaran jilid satu dipakai juga jilid dua sampai enam sebagai pedoman dasar, dengan penambahan beberapa petunjuk khusus sesuai muatan materi di masing-masing jilid. Berikut contoh dari petunjuk jilid satu nomor 7. Bagi santri yang betul-betul menguasai pelajaran dan sekiranya mampu berpacu dalam menyelesaikan belajarnya maka membacanya boleh diloncatloncatkan, tidak harus utuh sehalaman" (Humam, 2000). Adanya petunjuk pembelajaran, memudahkan pengajar menyampaikan materi dan pembelajar menguasai materi. Di samping itu, pembelajaran memiliki rambu-rambu yang baku untuk mencapai tujuan dan pembelajaran menjadi efektif dan efisien.

Sayangnya, ada tiga buku yang tidak memiliki petunjuk pembelajaran. Buku-buku tanpa petunjuk pembelajaran tidak memberikan gambaran bagaimana proses pembelajaran akan berlangsung untuk mencapai hasil yang maksimal dan tidak memberikan arah yang jelas terkait target pembelajaran sehingga output atau hasil pembelajan menjadi tidak bisa diukur.

Tabel 2 juga memberikan gambaran bahwa tidak semua buku tahsinul Qur'an menjadikan materi makhārijul huruf dan sifat-sifatnya sebagai fokus pembahasan. Padahal, kedua pokok

bahasan tersebut merupakan dasar atau pondasi membaca al-Qur'ān dengan tartil. Karakteristik bahasa al-Qur'ān banyak tergambar dari pengucapan huruf yang benar.

Data penelitian pada tabel 1 dan 2 diketahui bahwa buku (7), (8), dan (9) yang paling lengkap materi dan cara penyajiannya. Namun, ketiga buku itu pun masih perlu dikembangkan terkait dengan bentuk penyajian materinya agar pembelajaran lebih efektif.

Pembahasan Tabel 1 dan 2 menunjukkan semakin lengkap materi tahsinul Qur'ān semakin mudah memenuhi persyaratan membaca al-Qur'ān dengan tartil. Begitu pula semakin banyak bentuk varian penyajian semakin selaras dengan cara kerja alamiah otak. Pembelajaran yang membosankan akan direspon dengan emosi negatif oleh sistem limbik dan otak neokorteks tidak bisa bekerja dengan baik.Perasaan sulit memahami materi dapat diatasi dengan banyaknya bentuk penyajian materi.

Pembelajaran yang minim bentuk penyajian materi dapat menimbulkan kebosan. Begitu juga materi pembelajaran yang parsial (tidak lengkap) kurang dapat menunjang kompetensi inti dan kompotensi dasar karena tidak memenuhi prinsip-prinsip penyusunan materi. Ada tiga prinsip penyusunan materi pembelajaran, yaitu 1) relevansi: materi memiliki keterkaitan dengan pencapaian kompetensi dasar dan kompetensi inti; 2) konsistensi: materi memiliki keajekan dalam memuat pembahasan sesuai dengan kompentensi dasar yang harus dikuasai; dan 3) kecukupan: materi pembelajaran mencukupi untuk membantu siswa mencapai kompetensi dasar (Prastowo 2017).

Bentuk penyajian materi yang minim dapan menimbulkan kejenuhan dan penyedian materi yang tidak utuh dapat menimbulkan keraguan. Kedua faktor tersebut 
dapat menyebabkan sistem limbik memproduksi emosi negatif dan dikirim ke otak reptil supaya merespon dengan melawan atau keinginan meninggalkan pembelajaran. Otak neokorteks pun tidak dapat melakukan penalaran dengan adanya respon otak reptil aktif sehingga berujung pada kegagalan dalam belajar.

Pembelajaran menyenangkan, mudah, dan menantang dapat terwujud dengan penyajian materi yang lengkap (khususnya bagi pembelajar dewasa) dan penyajiannya banyak varian. Materi lengkap dapat memenuhi kebutuhan sifat curiosity (rasa ingin tahu) pembelajar, sehingga motivasi bagi pembelajar tumbuh dan dapat menjaga zona fokus pembelajar.

Gelombang alfa pembelajar dapat tercukupi oleh tersedianya berbagai varian penyajian materi pembelajaran. Berbagai varian penyajian materi dapat dijadikan ice breaking seperti parodi lagu dan brain gym (senam otak). Seperti, rumus praktis, dalam rangka menjaga kondisi kerilekan suasana namun otak dalam waspada siap menerima pembelajaran dan tetap fokus pada proses penalaran dan penyimpanan materi ke dalam storage otak.

Pembelajaran efektif dapat terwujud selama suasana pembelajaran selaras dengan kerja alamaiah otak, sesuai dengan teori pembelajaran model Barr dan Tagg yang dikutip Huda (2019). Varian penyajian materi seperti gambar, parodi lagu, encoding-decoding, video, rumus praktis, dan narasi dapat digunakan saling bergantian untuk menjadikan sistem limbik melahirkan emosi positif dan otak neokorteks bekerja dengan maksimal mengolah materi pembelajaran sehingga terwujud pembelajaran efektif.

\section{KESIMPULAN}

Buku-buku materi pembelajaran tahsinul Qur'an banyak yang belum memanfaatkan pendekatan berbasis neurosains. Buku-buku tersebut bisa dikembangkan dengan mengacu pada cara otak bekerja sehingga materi yang disampaikan menjadi bahan pembelajaran yang mudah, menyenangkan, dan menantang serta disukai pembelajar. Pembelajan tahsinul Qur'an berbasis neurosains memudahkan pembentukan pengetahuan dan karakter penuturannya dalam diri pembelajar dengan benar dan efektif. Penyajian materi tahsinul Qur'an dan penyajian materi dengan berbagai varian sejalan dengan kerja otak dan teori pembelajaran yang efektif. Penyediaan materi tahsinul Qur'an yang utuh menunjang kompetensi dasar dan inti sehingga memudahkan dalam usaha membaca Qur'an dengan tartil. Pembelajaran tahsinul Qur'an yang penuh keceriaan akan menumbuhkan neurotransmiter (asetikolin) yang merupakan pelumas terjadinyas jaringan sinapsis-sinapsis baru sebagai tanda bertambahnya kecerdasan pada otak. Bentuk-bentuk penyajian 
juga bisa diperkaya dengan narasi, rumus praktis, lagu, dan videoKomponen-konponen materi pembelajaran pun juga perlu diperhatikan untuk mendukung efektifitas pembelajaran dan memotivasi mereka untuk belajar dengan bersungguh-sungguh. Pembelajaran tahsinul Qur'an berbasis neuorosains perlu dikembangkan dan diadakan penelitian berkelanjutan, untuk penyempurnakan penelitian-penelitian yang ada.

\section{REFERENSI}

al-Qudhat, I. M., (2020). Wadhih fi Ahkkami at-Tajwid, Panduan Lengkap Belajar Ilmu Tajwid Otodidak. (Terjemahan Majid. A). Jakarta: PT Rene Turos Indonesia.

al-Quro, A. I. (tt). Tajwid dan Tahsin: Kaidah Tata Cara Membaca Al-Qur'an dan Tempat Keluarnya Huruf Disertai dengan Sifat-sifatnya. Tt: Mahkota Kita.

Annuri, A. (2019). Panduan Tahsin Tilawah Al-Qur'an \& Ilmu Tajwid. Jakarta: Pustaka Al-Kautsar. Ardianto, B. (2017). Memahami Otak Reptil, Sistem Limbik, dan Neokorteks pada Manusia. Tersedia pada: https://bramardianto.com/otak-reptil-sistem-limbik-dan-neokorteks.html.

Arsyad dan Salahudin. (2018). Hubungan Kemampuan Membaca Al-Qur'an dan Minat Belajar Siswa dengan Hasil Belajar Pendidikan Agama Islam. EDUKASI: Jurnal Pendidikan Agama dan Keagamaa. doi: https://dx.doi.org/10.32729/edukasi.v16i2.476.

Azmi, M. P. (2017). Asosiasi Antara Kemampuan Analogi dengan Komunikasi Matematik Siswa SMP. Al Jabar: Jurnal Pendidikan Matematika,8(1). doi: org/10.24042/ajpm.v8i1.902.

Awhinarto \& Suyadi. (2020). Otak Karakter dalam Pendidikan Islam: Analisis Kritis Pendidikan Karakter Islam Berbasis Neurosains. Jurnal Pendidikan Karakter. X(1). doi: https://doi.org/ 10.21831/jpk.v10i1.29693.

Damasio, A. (1994). Memahami Kerja Otak: Mengendalikan Emosi \& Mencerdaskan Nalar. (Terjemahan Yudi Santoso). Yogyakarta: Penerbit Baca.

Sousa, D. A. . (2012). Bagaimana Otak Belajar. Jakarta: PT. Indeks.

Departemen Agama. (2002). Al Qur'an dan Terjemahnya. Jakarta: CV Indah Press.

Hanafi, Y., Murtadho, N., \& Ikhsan, M. A. (2019). Literasi Al-Qur'an: Model Pembelajaran Tahsin-Tilawah Berbasis Talqin-Taqlid. Sidoharjo: Delta Pijar Khatulistiwa.

Hasanuddin. (2017). Biopsikologi Pembelajaran: Teori dan Aplikasi Banda Aceh: Syiah Kuala University Press Darussalam.

Hendri, E. (2020). Guru Berkualitas : Profesional dan Cerdas Emosi. Jurnal Guru, 1(2). Tersedia pada: http://file.upi.edu/Direktori/JURNAL/SAUNG_GURU/VOL._1_NO._2/Edi_HendriGURU_BERKUALITAS_PROFESIONAL_DAN_CERDAS_EMOSI.pdf.

Hidayat, N. S. (2012). Problematika Pembelajaran Bahasa Arab. An-Nida: Jurnal Pemikiran Islam. 37(1). Tersedia pada: http://ejournal.uin-suska.ac.id/index.php/Anida.

Huda, M. (2019). Model-Model Pengajaran dan Pembelajaran: Isu-Isu Metodis dan Paradidmatis. Yogyakarta: Pustaka Pelajar. 
Humam, A. (2000). Buku Iqro’ Cara Cepat belajar membaca Al-Qur'an. Yogyakarta: Balai Litbang LPTQ Nasional. . (2005). Cara Cepat Belajar Tajwid Praktis. Yogyakarta: Balai Litbang LPTQ Nasional.

Ilyas, Y. (2019). Kuliah Ulumul Qur'an. Yogyakarta: Itqan Publishing.

Iriani, T. dan Ramadhan, M.A. (2019). Perencanaan Pembelajaran untuk Kejujuran. Jakarta: Penerbit Kencana.

Kariadinata, R. (2012). Menumbuhkan Daya Nalar (Power Of Reason) Siswa Melalui Pembelajaran Analogi Matematika. Infinity: Jurnal Ilmiah Program Studi Matematika STKIP Siliwangi Bandung, 1 (1). doi: https://doi.org/10.22460/infinity.v1i1.p10-18.

LPPI UMY. (2019). Modul Pembelajaran Al-Qur'an: Diadopsi dari Buku 10 Jam Belajar Membaca Al-Qur'an oleh Prof. Dr. Muhammad Chirzin, M.Ag. Yogyakarta: LPPI Universitas Muhammadiyah Yogyakarta.

Miles, M. B., Huberman, A. M., \& Saldana, J. (2014). Qualitative Data Analysis: A Method Sourcebook. California: Sage Publications.

Muhimmah, I \& Suyadi. (2020). Neurosains dan Spiritualitas dalam Pendidikan Islam. Tadris : Jurnal Pendidikan Islam. 15 (1). doi: 10.19105/tjpi.v15i1.2880

Murniyetti, M., Zain, Z., dan Wirdati. (2012). Kemampuan Mahasiswa Membaca Al-Qur'ān di Universitas Negeri Padang (Studi Terhadap Mahasiswa Mata Kuliah PAI). FIS, Universitasn Negeri Padang. Tersedia pada: http://repository.unp.ac.id/1313/1/ MURNIYETTI_861_12.pdf http://repository.unp.ac.id/1313/1/MURNIYETTI_861_12.pdf

Nursalim, D (Ed). (2012). Al-Qur'ân Cordoba Amazing 33 Tuntunan Al-Qur'ân untuk Hidup Anda. Bandung: Cordoba Internasional-Indonesia.

Qowim, A. N. (2019), Internalisasi Karakter Qurani dengan Tartil Al-Qur'an. IQ (Ilmu Al-Qur'an): Jurnal Pendidikan Islam. 2 (1) doi: https://doi.org/10.37542/iq.v1i01

Prastowo, A. (2017). Menyusun Rencana Pelaksanaan Pembelajaran (RPP) Tematik Terpadu. Jakarta: Penerbit Kencana

Sa'diyah. K. (2013). Kualitas Pembelajaran Al-Qur"an dengan Metode Tartil di TPQ Sabilun Najah Sambiroto Taman Sidoarjo. Jurnal Pendidikan Islam (Journal of Islamic Education). 1(2), 268. doi: https://doi.org/10.15642/jpai.2013.1.2.267-286

Saeruddin \& Robith, A. S. (2011). Edisi Baru: Tuntunan Ilmu Tajwid Praktis. Surabaya: Penerbit Indah.

Said, A. \& Rahayu,D. R. (2017). Revolusi Mengajar Berbasis Neurosains. Jakarta: Kencana. Sholihuddin, M. (2008). Quantum Tahsinul Qur'an. Yogyakarta: Mavaza Publising.

Sudiarjo, A. Mariana, A.R. \& Nurhidayat, (2015). Aplikasi Pembelajaran Ilmu Tajwid, 
Waqaf dan Makharijul Huruf Berbasis Android. Jurnal Sisfotek Global. 5(2). doi: http://dx.doi.org/10.38101/sisfotek.v5i2.80.

Suherman, M., \& Lubis, M. A. F. (2017). Hubungan Kemampuan Membaca Alqur'an Dengan Hasil Belajar Mahasiswa Program Studi Teknik Mesin Politeknik Negeri Medan Studi KasusPada Politeknik Negeri Medan. Jurnal Ilmiah” INTEGRITAS . 3(2). Tersedia pada: http:// www.jurnalmudiraindure.com/wp-content/uploads/2018/01/ Supriyatno, H., Juanda., Solechan, M., \& Hidayani, N. (2007). Buku Ajar Al-Qur'an \& Tajwid.

Yogyakarta: LPPI UMY.

Suriasumantri, J. S. (2017). Filsafat Ilmu Sebuah Pengantar Populer. Jakarta: Pustaka Sinar Harapan.

Suwarno, R. W., Nurmahni., Rangkuti, D., Suseno, A., dan Aulassyahied, Q. (2019). Tahsinul Qur'ān Universitas Ahmad Dahlan. Yogyakarta; UAD LPSI \& UAD Press.

Suyadi, (2017). Teori Pembelajaran Anak usia Dini. Bandung: PT. Remaja Rosdakarya.

Titin, E. N. N. (2016). Penyusunan Perangkat Pembelajaran pada Materi Ruang Lingkup Biologi Kelas X SMA. Jurnal Pendidikan Matetamtika dan IPA, 7 (1).

Trinova, Z. (2012). Hakikat Belajar dan Bermain Menyenangkan bagi Peserta Didik. Al-Ta'lim Jurnal. 19(3). doi: https://doi.org/10.15548/jt.v19i3.55.

Widiana, I. W., \& Bayu, G. W. (2017). Pembelajaran Berbasis Otak (Brain Based Learning), Gaya Kognitif Kemampuan Berpikir Kreatif Dan Hasil Belajar Mahasiswa. Jurnal Pendidikan Indonesia (Indonesian of Education Journal. 6(1). doi: http://dx.doi.org/10.23887/jpiundiksha.v6i1.856 